\title{
Anatomical and Histological Study of Shark (Carcharhinus sorrah) Kidney
}

\author{
Hikmah Supriyati ${ }^{1 *}$, Rakhmiyati ${ }^{2}$, Muhammad Ja'far Luthfi ${ }^{3}$ \\ ${ }^{1}$ Postgraduate Biology Education Program, Yogyakarta State University, Indonesia. \\ ${ }^{2}$ Postgraduate Biosciences Program, Sebelas Maret University, Indonesia. \\ ${ }^{3}$ Biology Education Department, Faculty of Science and Technology, UIN Sunan Kalijaga, Indonesia.
}

\author{
Author correspondency*: \\ hikmahsupriyati@gmail.com
}

\begin{abstract}
Sharks are sea water fishes belong to the class Chondrichthyes, Subclass Elasmobranchii. Sharks are cartilaginous fish that have a different osmoregulation process than any other sea water fish. Cartilaginous fish is the only vertebrate that can maintain urea. This study aims to determine the anatomical and histological structure of the kidney in the anterior, medial and posterior parts of kidney. The study was conducted by observing anatomy of the kidney. Histological preparations were made using the paraffin method. Qualitative descriptive data analysis was done. Research results show that shark kidneys consist of three parts, namely the head kidney, the body kidney, and the tail kidney. Kidney sharks are brownish red with a size of $18 \mathrm{~cm}$ long. Histological observations of shark kidney in the head kidney reveals many glomerulus, body kidney reveals many distal and tubule proximal contractile tubules whereas tail kidney reveals stroma that is rarely found in vertebrate kidney.
\end{abstract}

Keywords: Sharks; Kidney; Anatomy; Histology

\section{INTRODUCTION}

Pisces are belonging to poikilothermic vertebrate (cold blooded) that live in water and breathe with gills. Every aquatic animal has osmotic pressure that is different from its environment, therefore aquatic animals must prevent excess water or lack of water so that the physiological processes in the body take place normally. Pisces is one of the taxa that has the largest member. They inhabit sea water, fresh water, mud and semi aquatic habitats. Therefore, the fish's kidney has a different structure and its histology is reflected by its habitat. The osmoregulation mechanism in pisces also varies depending on the environment or habitat (Fujaya, 2004).

Osmoregulation is a process of homeostasis to keep body fluids in a stable state. Excretion plays an important role in the removal of metabolic waste substances, especially those containing nitrogen so that these substances do not accumulate in the body. These metabolic waste substances may be able to disrupt homeostasis of the internal environment, especially those related to osmotic pressure and the stability ratio of ions in body fluids (Suripto, 1998).

The main excretory organ in vertebrates is kidney. Kidneys in vertebrates generally a pair. Embryologically, kidney originate from mesoderm. Kidneys in Pisces are different of those in frogs, lizards, birds, especially when compared to mammalian kidneys. There are three types of kidneys namely pronephros, mesonephros and metanephros. Fish kidney is the most primitive kidney among other vertebrate kidneys (Soesilo et al, 1994).

Each type of environment provides a variety of supporting factors typical for animals that live in it. The abilities and types of body organs possessed by each animal are different. Therefore, the osmoregulation mechanism by animals is also different and shows a very wide variation depending on the ability, osmoregulation organs that are owned, and the environmental conditions of each (Isnaeni, 2006).

Like aquatic animals, freshwater and sea water fishes have differences in osmoregulation and excretion. Freshwater fish have osmotic levels of body fluids that are hyperosmotic compared to their environment. Thus the fish will excrete a lot of water and hold ions (Lagler et al., 1997), whereas sea water fish have osmotic levels of body fluids that are hypo-osmotic in their environment. Therefore, fish must drink a lot of water (1/5 to $1 / 2$ of their body weight) and remove a lot of salt from their bodies (Suripto, 1998).

Sharks are water fishes and are included in the class Chondrichthyes (cartilaginous fish), Subclass Elasmobranchii. Seawater fish in general will drink a lot of water because it is to maintain bodyi fluids that are hypoosmatic on the environment. In contrast to Elasmobranchii which has a problem that is too little water intake. To overcome this animal produces a little urine. Even if only a little excreted, the urine can also be used to remove excess $\mathrm{NaCl}$ (Ville, 1988). 
These differences allow the organs involved in the osmoregulation process in sharks to have differences with kidney organs in other marine fish. Besides this research is also to find out the type of shark kidney. References about the anatomy and histology of sharks are still very rare, so researchers are interested in doing the research. Previous research has been carried out under the title anatomical and histological comparisons of the catfish uropoetic organs (Pangasius hypophtalmus) and sharks (Carcharhinus sorrah). This study discusses one field of view on shark kidney organs and catfish. The histological structure of the shark and catfish consists of glomerulus, distal tubules, proximal tubules and hematopoietic tissue. This research emphasizes the difference in shark glomerular diameter length which is smaller than that of catfish.

This researchs focus on the anatomy and histological structure of the kidney in the anterior, transition and posterior parts. This research discussed each histology structure of shark kidney, starting from many glomerulus and tubules in each part of kidney. In addition, this study discussed the histological structure that is likely to be rarely found in other vertebrates.

\section{MATERIAL AND METHODS}

\section{Material}

Test animals used in this study were five sharks obtained from Depok beach, Yogyakarta. The materials used in this study are HVS paper, bouin solution, graded alcohol $(30 \%, 40 \%, 50 \%, 60 \%, 70 \%, 80 \%, 90 \%, 95 \%$ and absolute), hematoxylin-eosin dyes, albumin, xylol, distilled water, entelan, toluene, absolute alcohol, paraffin, glassware, mask, gloves, needles and tweezers.

\section{Tool}

The tools used in this study were a set of surgical instruments, flakon bottles, paraffin tanks, paraffin ovens, beaker glasses, slide warmers, microtomes, staining jars, microscopes and computers.

\section{Procedure}

\section{Shark Dissection}

This research was conducted in April 2019 in the Zoology Laboratory of the Faculty of Science and Technology of UIN Sunan Kalijaga Yogyakarta. The sharks that has been sacrificed were then observed morphologically. Morphological observations included the gills, pectoral fins, dorsal fins, caudal fins, abdominal fins. Then the standard length, total length and fish height were measured.

\section{Anatomical observation}

Anatomical observation started with dissection performed from the posterior ventral to the anterior ventral. After the internal organs were observed, kidneys were taken and cut on three different parts, namely anterior (head), medial (body), and posterior (tail).

\section{Histological preparations}

This research was conducted from April to June 2019 in the Zoology Laboratory of the Faculty of Science and Technology of UIN Sunan Kalijaga Yogyakarta. The preparation of histology started with process of fixation which is the process of immersion of organs using a bouin fixative solution. Then the dehydration process was carried out with multilevel alcohol, clearing, infiltration, embedding, sectioning, staining with hematoxylin-eosin, and mounting process. Then observations using a binocular microscope (Suntoro, 1983).

\section{RESULTS AND DISCUSSION}

\section{Shark Morphology}

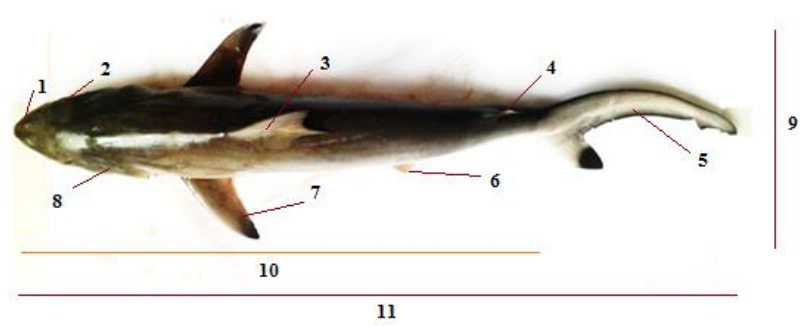

Figure 1. General shape and external parts of the shark's body: (1) Nostrils, (2) Eyes, (3) First dorsal fin, (4) Second dorsal fin, (5) Tail, (6) Fins rectum, (7) pectoral fins, (8) Gills, (9) Body height, (10) Standard length, (11) Total length (Manik, 2004).

Based on observations that had been done, sharks have an elongated body shape. Total length $74 \mathrm{~cm}$, standard length $53 \mathrm{~cm}$ and body height $21 \mathrm{~cm}$. The head is symmetrical and slightly small, has a long, rounded snout. Sharks have double dorsal fins. The anterior dorsal fin is larger than the posterior dorsal fin. The caudal fin is pointed, the dorsal caudal fin is longer than the ventral (Phillips, 1991). The type of shark's tail is heterocercal (Kardong, 2009). There are cloaca holes between the pelvis fins. In male sharks, caudal fins will turn into claspers (Organs to hug female sharks when mating) (Brotowijoyo, 1994). The dominant body color is black-brown, especially the dorsal, abdomen and caudal fins are rather brightly colored. Rows of teeth in the upper jaw are more triangular shaped. The gills open out with 5 gill slits located on the side of the head (Jones \& Larson; 1974).

\section{Anatomy of Shark Kidney}

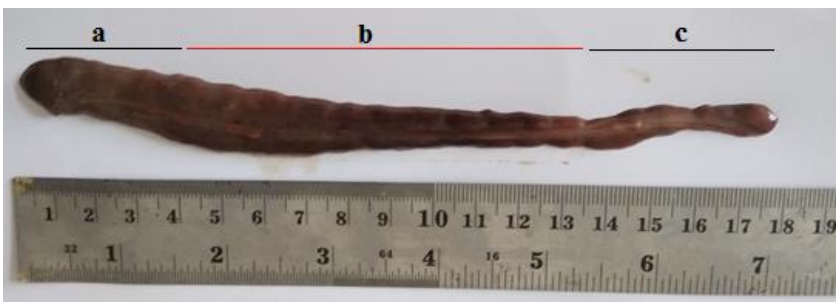

Figure 2. Anatomy of a shark kidney: (a) the anterior part (head kidney), (b) the transition part (body kidney), (c) the posterior part (tail kidney). 
Anatomy observations show that shark kidney consists of a pair of kidneys that are located along body cavities, ventral to vertebrae. Shark's kidney has an elongated shape and is brown in color. The shark's length is $18 \mathrm{~cm}$. Shark's kidney consists of three parts, namely the anterior part (head kidney), the medial part (body kidney), the posterior part (tail kidney). Adult fish kidney is mesonephros kidney which consists of 70-80 tubules that form the mesonephric duct (Vize, 2012).

Sharks are cartilaginous fish which differ in the osmoregulation process compared to other sea water fish. Cartilaginous fish is the only vertebrate that can maintain urea. Excess urea will be excreted by the kidneys and gills. Cartilage is able to restore blood urea from the filtrate. As a result, blood contains urea that is sufficient to be hyperosmotic to seawater (Hildebrand, 1995). The existence of this process makes blood concentration closer to seawater concentration. So that sharks do not need to drink excess sea water. Whereas to overcome dehydration sharks also absorb water through the gills and can produce runny urine (Castro \& Huber, 2005)

In most animals, urea is poisonous and excreted, but sharks excrete only small amounts. Urea and related compounds are not so toxic to cartilaginous fish. The concentration of urea in shark's body fluids can reach 100 times the level of mammalian urea (Villee, 1999). Excess salt is excreted by the kidneys, intestines, and special glands near the anus called the rectal glands. This gland can help regulate how to deal with excess ions, especially urea. Excess urea in the shark's body will be removed through the gills and rectal glands (Castro \& Huber, 2005).

\section{Histology of Shark Kidney}

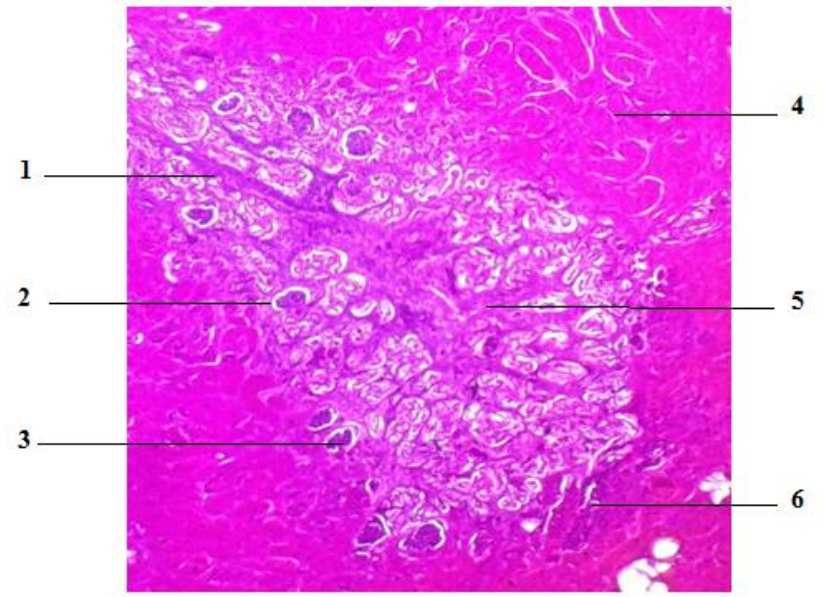

Figure 3. Histology of anterior shark kidney: (1) Medulla, (2) Bowman capsules, (3) Glomerulus, (4) Cortex, (5) Radius medullaris, (6) Lymphoid tissue, (7) Distal tubule, (8) Proximal tubule

Based on histological observations that have been made that there is a cortex in the kidneys of sharks. The cortex is in a capsule and is dark color (Yatim, 1996). Kidney capsules in the form of irregular solid connective tissue. The cortex contains the proximal tubule, distal tubule, glomeruli and medullary radius. The medullaris radius is formed by straight nephrons, blood vessels, and collagen tubules that fuse in the medulla (Eroschenko, 2010).

Medulla is the innermost part of the kidney, under the cortex, light colored. Medulla contains bundles of vessels and urinary collection vessels, which number in millions according to many malphigian bodies. A Malphigian body along with its veins is an autonomous unit of disposal equipment, called a nephron. It is estimated that each hemisphere of the left-right kidney contains two million nephrons. The direction to the medulla renal sinus forms many bulges, called the malphigi's pyramid. The top of each pyramid is called a papilla. Apart from the medulla and cortex on the anterior part of the shark kidney there are also many glomerulus. Glomerulus is an anastomotic clot of capillaries. The part that covers the glomerulus is the bowman capsule. The bowman capsule is a ball shape basin that is not full (Yatim, 1996). In addition to the anterior part of the kidney there is also a lymphoid tissue (hematopoietic). This network is composed of reticular fibers (Subowo, 1992).



Figure 4. Histology of the transitional shark kidney (body kidney: (1) distal contour tubules, (2) proximal tubule tubules.

Based on observations that have been made that in the transition (body) histology of shark kidney there are many proximal tubule and distal contour tubules. The proximal tubule is longer than the distal tubule. The proximal tubule has one layer of cuboid cells with a granular and eosinophilic cytoplasm. Whereas the distal tubule is shorter and the number is less in the cortex. The distal tubule has a larger lumen within cells (Eroschenko, 2010). The number of proximal tubules and distal tubules in the transitional part of the kidney (body kidney) allows the process of reabsorption to occur. The absorbed substances are glucose, protein, 
amino acids and carbohydrates. Related to its function the presence of distal tubules also results in ion transport. This is related to the maintenance of acid-base in the blood (Ramaley \& Bevelender, 1979).

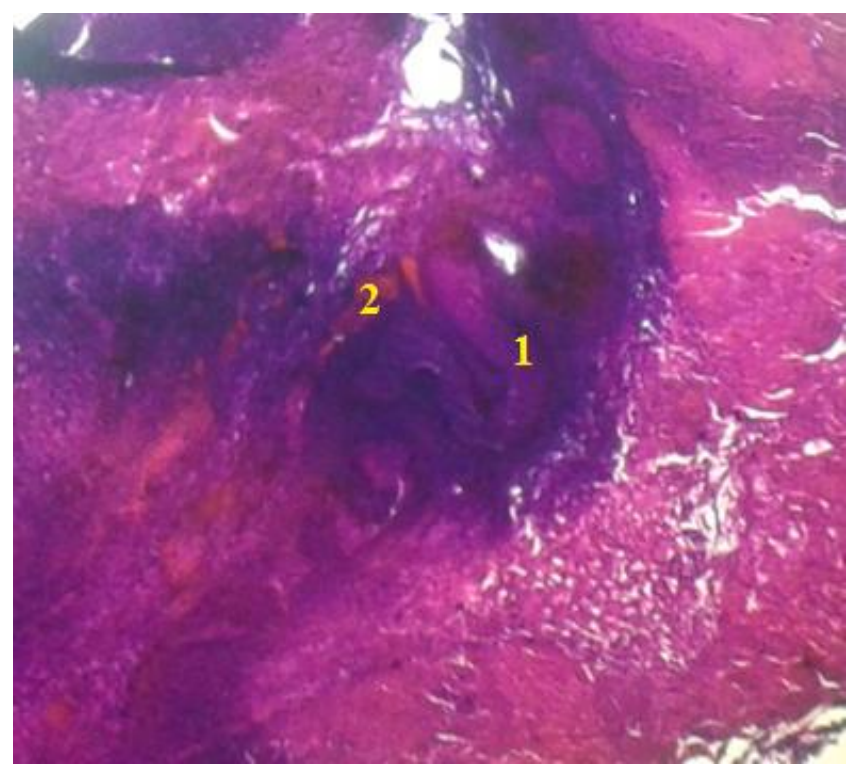

Figure 5. Histology of the posterior shark kidney: (1) Stroma, (2) Blood vessels.

Based on histological observation at the posterior kidney there is a stroma. Renal stroma is rarely found in vertebrate, stroma consists of loose connective tissue that accompanies blood vessels, lymph vessels and nerves. In the stroma there are cells that occupy the gaps between the 3 dimensional webbing which are composed of reticular fibers, reticular cells and macrophage cells (Subowo, 1992).

Basically, the vertebrate kidney has the same structure, namely the glomerulus and tubules. But in each class there are different arrangements. The anterior part of shark kidneys has a lot of glomerulus which in this part allows the filtration process to occur. While in the transition (body kidney) there are many proximal tubules and distal tubules. The results of this research are consistent with the theory by Villee (1999) that in the kidney of the fish the anterior tubules have disappeared, several tubules in the middle region are related to the testes, and there is a concentration and multiplying of the posterior tube. In addition there are also archinephric ducts that function as excretion and sperm ducts in males. While the tail of the kidney (posterior kidney) there is a stroma. Stroma is usually found in mammals and is rarely found in vertebrate kidneys (Subowo, 1992).

\section{CONCLUSION}

Based on research that has been done, it can be concluded that, shark kidneys consist of three parts, namely the head kidney (anterior), body kidney (transition), and tail kidney (posterior). Kidney shark brownish red with a size of $18 \mathrm{~cm}$. While histological observations of the anterior kidney there are many glomerulus, transition kidney there are many distal tubule, proximal tubule and in the tail kidney there is a stroma, where the stroma is very rarely found in vertebrate kidney.

\section{REFERENCES}

Brotowidjoyo, Mukayat Djarubito. 1994. Zoologi Dasar. Jakarta: Erlangga

Castro Peter dan Huber Michael. 2005. Marine Biology Fifth Edition. New York: Mc Graw Hill Companies Inc

Dellmann, H dan Brown Esther.1989. Textbook of Veterinary Histology. Amerika: Lea \& Febiger

Eroschenko, Victor. 2010. diFiore's Atlas of Histology with Functional Correlation, 11 th $\mathrm{Ed}$. USA: EGC Medical Publisher

Fujaya, Y. 2004. Fisiologi Ikan Dasar Pengembangan Teknik Perikanan. Jakarta: PT Rineka Cipta

Hildebrsnd, Milton.1995. Analysis of Vertebrate Structure Fourth Edition. United States of America: R.R DonnelleyCrawfordsville

Isnaeni, wiwi. 2006. Fisiologi Hewan. Yogyakarta: PT Kanisius

Jones, R, T and H.K, Larson 1974. A key To The Families of Fishes As Recorded From Guam. Univ. of Guam, The Marine Laboratory, Tech. Rep. (10): 1-4.

Kisia, Seh M. 2009. Vertebrates: Structures and Functions. USA: Science Publishers

Lagler, K. F., J.E. Bardach, R. R. Miller dan D. R. M. Passino. 1997. Ichtyologi 2nd ed. John Wiley \& Sons. New York.

Manik, Nurdin. 2004. Mengenal Beberapa Jenis Hiu. Jurnal Oseana, Volume XXIX No (1): 9-17

Mescher, Anthony. 2010. Junquera's Basic Histology: Text and Atlas, $12^{\text {th }}$ Ed. New York: Mc Graw Hill Companies Inc and EGC Medical Publisher

Ramaley dan Bevelender. 1979. Dasar-Dasar Histologi: Edisi Kedelapan. (Alih bahasa oleh Ir Wisnu Gunarso). Jakarta: Erlangga

Soesilo, Nyoman dkk. 1994. Anatomi Hewan. Jakarta: Universitas Terbuka

Soewolo. 2000. Pengantar Fisiologi Hewan. Jakarta: Proyek Pengembangan Guru Sekolah Menengah IBRD Loan No 3979, Direktorat Jenderal Pendidikan Tinggi Departemen Pendidikan Nasional

Subowo. 1992. Histologi Umum. Jakarta: Bumi Aksara

Suntoro, S. H, 1983. Metode Pewarnaan Histologi dan Histokimia. Jakarta: Bhratara Karya Aksara.

Suripto. 1998. Fisiologi Hewan. Bandung: ITB Press

Villee, C. A; W. F Walker dan R. D Burner. 1988. Zoologi Umum. Jakarta: Erlangga.

Villee, Claude A et.all. 1999. General Zoology: Sixth Edition (Alih Bahasa Prof. Dr. Nawangsari Sugiri). Jakarta: Erlangga

Yatim, Wildan. 1996. Biologi Modern: Histologi.Bandung: PT Tarsito. 